\title{
South Africa's Strategic Investment on its National Security in Southern Africa
}

\author{
Sehlare Makgetlaneng \\ School of Social Sciences \\ University of Limpopo, South Africa
}

\begin{abstract}
South Africa is a country of global, continental and regional strategic importance. It is a global actor with the well-entrenched and long-standing international political and corporate role and presence and relative global strength. It is Africa's qualitatively largest and strongest diversified economy. It is African continental and Southern African regional power with considerable continental and regional strength. These factors give it enormous advantages and privileges in playing a leading role in African affairs. They also, dialectically, serve as its key challenges it faces in its efforts to structurally transform its society and to contribute towards structural regional and continental restructuring. How given these factors should South Africa strategically invest on its national security in Southern Africa - the region where it has considerable power and authority a region whose dependence upon it is a dominated process? There is a fundamental need for this process to be substantially reduced for South Africa's long-term strategic interests. Its sustainable national security and increased progressive role in African affairs require truly regional allies in a requisite position to come to its aid in a period of its urgent need. Weak regional countries crucially depending on South Africa are of less importance to it. The achievement of their sustainable development is in the long-term strategic interests of South Africa in its internal and external relations. It is not only regional countries which need South Africa for their national security. South Africa also critically needs them particularly as a country expected to substantially increase its leading role in the structural regional and continental transformation. Its sustainable national security lies not only with the majority of its people, based on the satisfaction of their interests, investing on its defence, but also with the structurally restructured region walking together with it in the advancement of the structural continental transformation.
\end{abstract}

Keywords: strategic investment; sustainable national security; Southern Africa;

\section{South Africa's Global, Continental and Regional Strategic Importance}


South Africa is a country of global, continental and regional strategic importance. Its global, continental and regional status is characterised by its position in a hierarchy of political, economic, financial, trade, human resources development, technological and military international power relations that extends from the United States of America at the centre of capitalism to the African continent and its Southern African region at its periphery. It is a continental power and a regional power consolidating its continental and regional status and striving to be an important international power, a major force within the Group of 20 countries and a formation consisting of Brazil, Russia, India, China and South Africa (BRICS) and an important actor within the United Nations Organisation as a permanent member of its Security Council. It has made it impossible for any organisation established by the United Nations members committed to end the Western domination of the world and to the restructuring of the global governance and its multilateral institutions theoretically and practically concerned with African affairs and striving to have meaningful and sustainable closer working relations with Africa to exclude it from its membership.

South Africa as Africa's qualitatively largest and strongest diversified economy, its capital accumulation process, relative international strength and considerable continental and regional strength give it enormous advantages and privileges to play a leading role in African affairs. Its global, continental and regional strategic importance helps to explain why there is a high level of expectations and demands placed upon it globally, continentally and regionally to increase its role in African affairs and transformation. This reality is articulated not only by politicians but also by intellectuals. Fidel Castro (1998:6), in his address to the South African Parliament in Cape Town on 4 September 1998, articulated it as follows:

From the new South Africa, the hope of a new Africa can emerge. Looked at economically, from the industrial, agricultural, technological and scientific points of view, South Africa is the most developed country on the African continent. Its energy and mineral resources are innumerable and in many of them, South Africa is very highly ranked world-wide. Today, South Africa produces $50 \%$ of the electricity of the entire continent, $85 \%$ of the steel and $97 \%$ of the coal. It accounts for the transport of $69 \%$ of all the railway freight, has $32 \%$ of all motorized vehicles, and $45 \%$ of all paved roads on the continent".

According to Castro, post-apartheid South Africa is not only "the hope" for the emergence of "a new Africa", but also of "a new world". It is the hope for the emergence of a new world in the sense that "tomorrow" it "could become the example of brotherhood", sisterhood "and justice" (Ibid.) or "a model of a more just and more humane future" (Ibid., 6). 
Jakaya Mrisho Kikwete as the president of Tanzania, on state visit to South Africa from 18 to 21 July 2011, called upon South Africa to shoulder its "leadership responsibility" in African affairs. Maintaining that it is "Africa's only economic, political and military power of significance" and urging it to play a leading role in Africa, he concluded: "Therefore, South Africa has a leadership responsibility on the African continent. South Africa has to play that role and you cannot shy away from it. If you don't perform that duty, we'll suspect your intentions" (Kikwete 2012:4).

Manuel Castells (1996) contends that for those controlling global capitalism, post-apartheid South Africa provided hope for the continent during the 1980s when "most of Africa" was facing profound economic and financial problems. Castells (1996:136) concluded that:

This is why the most hopeful prospects for future development in Africa come from the potential role that could be played by the new, democratic, black-majority South Africa, with strong economic and technological linkages to the global economy. The stability and prosperity of South Africa, and its willingness and capacity to lead its neighbors as primus inter pares, offers the best chance to avoid the human holocaust that threatens Africa, and through Africa, the sense of humanity in all of us.

Achille Mbembe (2019) maintains that South Africa is well-positioned to lead the struggle against racism and white supremacy and their consequences globally. According to him, it is "arguably the one place on Earth with the best chance of radically undoing the extraordinary damage" racism and "the structures of white supremacy" inflicted upon a huge portion of humanity" (Mbembe 2019:28). It "could objectively become a paradigmatic instantiation of the entanglement of our world" (Ibid.). It is "the only nation on the planet where black people rule over a powerful white minority" (Mbembe 2008:6). Given this reality and the fact that it is "the most powerful country in the continent", how its black people "think about themselves, imagine their own history and memorialise their losses will determine" not only "the fate" of its "fragile experiment in democracy", but also "whether or not white people have a future in the continent" (Ibid.).

Mbembe maintains that for South Africa to "lead the world into undoing the damage racism has inflicted on the idea of democracy", its black people should move decisively against what he refers to as their intellectual and political limitations. He argues that these limitations can best be understood if we come to grips with the reality that:

Although black South Africans are at the helm of the most powerful country in the continent, many still think and act as if they were powerless. Their belief in the ability to effect meaningful social change is minimal. Feeling betrayed by the present, the law and 
democracy itself, they are willing to experiment with populism and various forms of lumpen-radicalism as evidenced by the increasingly strident appeals to kill for and die for the leader" (Mbembe 2008:6).

Black people are indispensable to the maintenance of the status quo and to its elimination in the country. If the status quo will continue being maintained, it will because of the programme of action successfully embarked upon by blacks who are against the qualitative improvement of the material conditions and rights of the majority of South Africans. The elimination of the status quo will be a result of the programme of action successfully embarked upon also by blacks who are for the national transformation.

One of the key reasons why a high level of expectations and demands are placed upon South Africa globally and continentally for it to play an increasing role in African affairs in the contribution towards the achievement of the interests of the people of Africa is because it constitutes a potentially powerful centre of independent development on the continent. The materialisation of this possibility or potential depends on its unassailable political leadership and its commitment to the rational utilisation of resources for its self-sustainable development. These factors translate into political power and authority which it should increasingly and progressively use in African and global affairs.

\section{South Africa in a Strategic Region for the Western Interests in Africa}

South Africa is in a region occupying a key strategic position in the plans of the Western powers for their continued control of Africa's resources. In the early 1950s, upon the assumption of the leadership of corporate imperialism, the United States increased its preparation for this control of the continent's resources to survive the end of its colonial era. The Council on Foreign Relations, working together with the Ford Foundation, the Rockefeller Foundation and intellectuals, devoted its energies to "emerging problems of American foreign policy in Africa" in its discussion meetings in 1953 for the United States to have access to and control of Africa's resources. These meetings were led by Vernon McKay, James C. Coleman and Archibald Campbell on 5 February 1953, 4 March 1953 and 7 April 1953 respectively. Richard Glotzer maintains that, based on the reports of these meetings, according to the council:

In descending order of importance, United States interests in Africa were determined to be: maintain Africa as a supply center and the base of air operations; West Africa's proximity to Brazil; Africa's abundance of strategic materials for stockpiling; expanded 
opportunities for trade; and "humanitarian interest" and sympathy with self-determination (Glotzer 2009: 429).

One of these intellectuals was Willem Cornelis de Kiewiet, a South African historian, who served as acting president of Cornell University and the president of the Rochester University, the president of the American Association of Universities and the Council of Learned Societies. Upon joining the Council on Foreign Relations per invitation of its leader, David Rockefeller, he worked closely with the Ford Foundation, the Rockefeller Foundation, corporate leaders and intellectuals with links with government like Dean Rusk of Harvard University who later became the Secretary of State. He chaired its Board of Directors from 1952 to 1954 and served as a member of its Study Group on the Colonial Problem. Hendrik Bernardus Thom, as the rector of the Stellenbosch University and a chairperson of the Broederbond, worked closely with him on faculty exchanges between the United States and South African universities.

De Kiewiet served as the Carnegie Corporation's advisor on Africa. Focusing on South Africa and Southern Africa, its position that South Africa is of strategic importance to the interests of the United States regionally and continentally was supported by the fact that as "of 1940, when most grant making ground to a halt in anticipation of war" on a global scale, "the corporation's expenditures in the Union of South Africa accounted for half of its total African outputs" (Ibid., 424). His service to the United States in African affairs as an intellectual was part of his position that universities should play a strategic role in the policy arena in a rapidly changing world environment in which the Unites States was posed to be a dominant international actor. The Central Intelligence Agency worked with him through its Bureau of African Affairs because of his understanding of Africa and his strategic thinking in the service to the United States national security interests. He articulated his position on the colonial rule in 1956 in his testimony to the Foreign Policy and Mutual Security Subcommittee of the United States Senate's Foreign Relations Committee. Asked questions, among others, on the United States position on Algeria and Southern Africa, he maintained that the colonised people should be immediately freed from the colonial rule was misguided. For him, the real focus of the Western powers should be on the viability of the post-colonial state (Ibid., 435).

The position occupied by Southern Africa in the plans of the Western powers for their continued control of Africa's resources constitutes key fundamental challenges its countries face in the resolution of their national question. This reality supports advice provided by Cyril Lionel Robert James of how the relationship between the class question and the race question in politics and imperialism should be viewed particularly in the struggle for the equality of material conditions 
and rights. He maintains and defends the thesis of the primacy of the class question over the race question in the social relations of classes with antagonistic class interests in capitalist societies.According to him, the fact that the race question is a secondary issue in relation to the class question in terms of importance, means that its importance should be neither overestimated nor underestimated. The dynamic relationship between the class question and the race question should be viewed and examined dialectically. Providing analysis of their organic relationship and demonstrating that capitalism structurally buttresses racism, James never departed from the importance of the racial factor in his view of politics and imperialism. The point is that the reality that the race question is a subsidiary or secondary issue in relation to the class question does not mean that the importance of the race question should be neglected or minimised. James articulates this reality as follows: "The race question is subsidiary to the class question in politics, and to think of imperialism in terms of race is disastrous. But to neglect the racial factor as merely incidental [is] an error only less grave than to make it fundamental" (James 1963:283).

This is the lesson for the people of Southern Africa in their view of the relationship between the class question and the race question in politics and imperialism. They should dialectically weave the relationship between these two questions and never depart from the importance of the racial factor in their intellectual and political project of resolving their national question. This task is required by the Southern African struggle for the equality of the material conditions and rights. The advice provided by James on how to view the relationship between the class question and the race question in politics and imperialism and never to depart from the importance of the racial factor is of crucial political, economic and ideological importance to the Southern African progressive forces in their region's internal and external relations. It is of vital importance particularly given the fact that their regional transformation process is a theoretical and political project. It is a substantial and welcome addition to confronting challenges faced in the resolution of the national question in the region.

Sam C. Nolutshungu in 1993 articulated the importance of the racial factor in apartheid South Africa's foreign policy and its continued role in post-apartheid South Africa. In his words:

South Africa's success in the field of foreign policy owed a great deal to the fact that that publics in the dominant countries had a great deal of sympathy for independence of ideology, or any precise calculation of economic advantages. A government of dark-skinned people is not likely to attract either as much investor confidence or popular sympathy in the West where, despite the anti-apartheid campaigns, the silent majorities remained deeply sympathetic to white South Africa. Indeed, all the negative presumptions with which the 
emergence of black governments has been met elsewhere will be also apply here (Nolutshungu 1994:133).

The position that Southern Africa occupies a key strategic position in the plans of the Western powers for their continued control of Africa's resources is articulated by David Cherry as follows: Any plans of the Anglo-American powers for Africa will have, as a major motivation, the increased exploitation of Africa as a base of operations, a source of oil and gas, and a source of mineral wealth, especially those metals - platinum, chromium, manganese needed for advanced military technology that are not widely dispersed in the Earth's crust, but are found in Southern Africa (Cherry 2002:20).

South Africa occupies a leading position within this process. It is a target not in its own right by the Western powers in their defence of their interests. It is this strategic importance which structurally renders it as the country facing more challenges than any other African country in the struggle for its national transformation. Their South Africa policy is characterised by a united front of commonality of interests and common patterns of co-operation, the long-term strategic goal, transcending internal contradictions and changing short-term objectives which is that it must remain under their domination.

South Africa's response to their policy should be programmes of action whose primary aim is to satisfy the popular needs and demands of its national relations. It should include efforts to change the balance of forces regionally, continentally and globally required by the advancement of its long-term strategic interests. What should it do in contributing towards the creation of the regional environment conducive for the advancement of these interests?

South Africa's investment in its national security regionally calls upon it to substantially increase its investment on its military. Its political, economic, financial, trade, human capital or human resources development and technological power is not enough for the successful execution of the task of creating its sustainable national security in the region. It should have a requisite military power for it to become a regional and continental military power. It should ensure that its military force is credible not only because it is well-equipped, but is also, most importantly, battle-tested. Thanks to it being a military power with the battle-tested army, its demands will be paid careful attention to in regional, continental and global affairs.

The consolidation of South Africa's centrality in Southern African and African affairs requires its requisite military power for the effective pursuit of its African and global policy. Its requisite 
military power will complement the efforts of its political, economic, financial, trade, human capital or human development and technological power in the theatre of the advancement of its interests regionally, continentally and globally. The articulated combination of its political, economic, financial, trade, human capital or human development and technological power and its military power as the requisite proud national asset in its Southern Africa and Africa policy is essential for the consolidation of its position at the centre of the regional and continental affairs.

Secondly, South Africa should intensify its regional and continental obligation in contributing towards the transformation of the Southern African Development Community (SADC) and the African Union (AU) through contributing towards the structural restructuring of their members. This task entails contributing towards the creation and sustenance of political, economic and ideological and institutional space for African countries to define their destiny and defeat agendas imposed on them by external powers (Jordan 2004:11). Nelson Mandela as the president of South Africa served as a substantial and welcome addition to the execution of this task by South Africa in its Southern Africa foreign policy. He articulated the strategic importance on the part of African political leaders to put the people of Africa and their human rights, democracy and development and political governance conducive for their advancement at the centre of advocacy, debate and policy in his view of African diplomacy. This task structurally put him in disagreement with his fellow African leaders on these issues and processes. He articulated this disagreement with them in public at their official meetings. At the SADC heads of state and government summit in Blantyre, Malawi on 8 September 1997, Mandela told his fellow leaders in his opening address that: Our dream of Africa's rebirth as we enter the new millennium, depends as much as anything on each country and each regional grouping on the continent, committing itself to the principles of democracy, respect for human rights and the basic tenets of good governance (Mandela 1997b).

The fact that SADC's "basic principles are respect for the sovereignty of member states and non-interference in one another's internal affairs" and that this is "the basis of good governance on the inter-state level" does not mean that their "considerations" must "blunt or override our common concern for democracy, human rights and good governance in all our constituent states". Southern African leaders are under obligation to defend principles of the SADC Treaty whose "obligations bind" them to "undertake measures to promote the achievement of the SADC's objectives and to refrain from any measures likely to jeopardise the sustenance of these principles" (Ibid.). 
Mandela reminded his fellow leaders that the "right of citizens to participate in political activities in the country of their birth unhindered is a non-negotiable basic principle to which we all subscribe" and that the "creation of structures within public opinion can be mobilised and given public expression is undeniably part of the democratic process" (Ibid.). Pointing out that it is of vital importance, as regional leaders, that they "must reflect on how far" they "support the democratic process and respect for human rights", he concluded that:

Can we continue to give comfort to member states whose actions go so diametrically against the values and principles we hold so dear and for which we struggled so long and so hard? Where we have, as we sadly do, instances of member states denying their citizens these basic rights, what should we as an organisation do or say? These are difficult questions. But we have to ponder them seriously if we wish to retain credibility as an organisation genuinely committed to democracy, human rights and good governance - and, perhaps even more importantly, if we are to have as our supreme mission the eradication of the suffering - social, economic and political - of the people of our region and its constituent countries" (Ibid.).

He called upon his fellow SADC leaders to answer these questions by solving problems faced by the African people and opposing them where they occur throughout the continent. In his closing address, he reminded them about their obligation to the people of the region:

The test of our success will ultimately be how much we provide for the best human needs of our people through the creation of more jobs, social security, housing and access to adequate medical care, eradication of illiteracy, water provision and a safe and sustainable environment" (Mandela 1997a).

This was the test of a new renaissance in the conduct of African diplomacy. It called upon those in power to regard the people as the national asset, their governing parties as their organisational servants and themselves as truly public servants advancing human needs, creation and sustenance of employment and wealth opportunities, social services, peace and security and eradication of human debasement and despicable conditions. Mandela was registering his opposition to the statecentred view of national sovereignty. According to him, national sovereignty should not be subject to the state-centric perspective of international relations. It should be viewed as the governance right exercised primarily in advancing the material conditions and rights of the African people. It is the respect for their right in ensuring that domestic and foreign policies of their countries are 
exercised within the context of the satisfaction of their democratic rights, development and security needs. It is also the respect for their right to freely and independently mobilise themselves to ensure that their national governments do justice to their function in protecting them as citizens. This is the state's obligation to citizens which it fulfils through national governments. The protection of citizens by the state is not negotiable. It is the function of any government.

Mandela's call for a new renaissance in the conduct of African diplomacy based on the advancement of the material conditions and rights of the African people is the right of African countries to their national self-determination and the free, independent exercise of their sovereignty and domestic and foreign policies. The execution of the task by South Africa in contributing towards the structural restructuring of African societies through its national transformation is the investment on its security not only regionally, continentally and globally, but also nationally within itself.

South Africa as a country more developed than any other African country calls for an increase in its investment on its security regionally. The key strategic issue is the dialectical meaning of its status in relation to all African countries not only those in Southern Africa. Its meaning is that it is dominated by imperialism more than any other African country (Nkrumah 1970:12). Maintaining that South Africa is "the most highly industrialised sector of the African continent" (Ibid., 4), Kwame Nkrumah concluded that it is dominated by imperialism more than any other African country.

What should be the starting point in South Africa's Southern Africa policy? Its starting point in its regional policy is that it should have a room for the possibility of it facing profound unprecedented national problems. Secondly, it should have a room for the materialisation of this possibility. Thirdly, it should ask itself the question as to which country in the region will be wellpositioned to come to its aid in the period of its urgent need when facing these problems. Its answer to this question is that it has no alternative except to effect its structural national transformation. Its best and most effective way to contribute towards the restructuring of the region is through its national transformation. By contributing towards the regional restructuring through its own national transformation, it will bring into existence its real, genuine regional allies who will significantly reduce dependence of their countries on itself. The consequence of this development is that it will be together with its SADC allies contributing towards the continental transformation and integration. Their contribution towards the continental change will help to create the continental environment conducive for their national security. It is through the creation of a better Southern Africa and Africa that South Africa and its continental allies will contribute 
towards a better world. South Africa's contribution towards a better Africa and a better world is its investment on its national security not only continentally and globally, but also, of grave import, internally within itself.

It is of vital importance for South Africa to highly appreciate and treasure invaluable advice of its leader, Oliver Reginald Tambo (1997), whose unassailable leadership of the African National Congress (ANC) mobilised its people and the people of the world towards their successful walking together in ending its apartheid era. Tambo advised the ANC in its struggle to be its governing party to learn not only from its allies, but also from "the enemy" and "avoid its mistakes". The point is that, for him, "the enemy is not necessarily doing everything wrong". Given this, avoiding "repeating the enemy's mistakes", it "may take" its "right tactics and use them to" its "advantage" in the advancement of its strategic interests. In ensuring that post-colonial African countries, especially those in Southern Africa should not actively support the ANC in its struggle to end the apartheid rule, apartheid South Africa was investing strategically on its national security not only regionally and continentally, but also, of grave import, internally in South Africa. Post-apartheid South Africa's active contribution towards a better Southern Africa and Africa advancing material interests and rights of their people is a solid investment on its sustainable national security. Mandela, in putting material interests and rights of the people of Africa and the world at the centre of South Africa's post-apartheid foreign policy, had this in mind when he maintained that "South Africa cannot escape its African destiny. If we do not devote our energies to this continent, we too could fall victim to the forces that brought ruin to its various parts" (Mandela 1993:88).

South Africa could also, in avoiding repeating "mistakes" of the United States which led the Western powers in their support to the apartheid regime, learn from it in the conduct of its foreign policy and use "its tactics" to its "advantage" in the advancement of its strategic interests. In this context, it should take into account Susan Elizabeth Rice's explanation of the strategic objectives of the United States Africa policy and act accordingly in its foreign policy. Rice, African-American, served as the 24th United States National Security Advisor to President Barack Hussein Obama from 2013 to 2017, the United States Ambassador to the United Nations from 2009 to 2013, United States Assistant Secretary of State for African Affairs from 1997 to 2003, and Special Assistant to President William J. Clinton and Senior Director for African Affairs at the National Security Council at the White House, as well as Director of for International Organisations and Peacekeeping on the National Security Council staff from 1993 to 1997.

According to Rice, the issue of access to and control of Africa's resources is the strategic investment of the United States on its national security. She articulates the United States strategic 
foreign policy imperative as follows: "Our first interest in Africa, as elsewhere, is defending our own national security and protecting Americans in the United States and abroad" (Rice 1999:2). Regarding Africa as "the largest untapped market for the U.S. in the world," a "market of approximately 700 million potential consumers," which "truly represents the last frontier for the United States exporters and investors" whose "potential for tomorrow's creative entrepreneurs is explosive, especially in the natural sector, consumer products, agribusiness, infrastructure and telecommunications" (Ibid., 4) upon which it "relies heavily" for "petroleum and strategic minerals," including bauxite, cobalt, copper, diamonds, gold, manganese, platinum and uranium (Ibid.), she articulates the United States' strategic value of continuity in this investment as follows: “We must invest the United States' commitment, talent, resources, and energy in Africa in order to promote lasting peace, security and prosperity here at home" (Ibid., 6). She emphasises that "Africa's importance to the economic well-being of the U.S. is self-evident" (Ibid., 3). It is in South Africa that the United States has enormously invested for the security of its interests and safety of its operations regionally and continentally. This is structurally required by the satisfaction of its national security interests.

Rice supports James's position that the class question is more important than the race question in politics and imperialism in articulating her aggressive, combative, chauvinist, arrogant, reckless and militaristic view of Africa clearly in no uncertain terms. Her view of the continent is characterised by her position that it is the threat to the United States national security, that it is "the world's soft underbelly for global terrorism" and that it is the nerve centre of terrorist organisations or "terrorist networks". In her words:

"Much of Africa is a veritable incubator for the foot soldiers of terrorism. Its poor, overwhelmingly young, disaffected, unhealthy and under-educated populations often have no stake in government, no faith in the future and harbor an easily exploitable discontent with the status quo. For such people, in such places, nihilism is a natural response to their circumstances as self-help. Violence and crime may be at least as attractive as hard work. Perhaps that is part of the reason why we have seen an increase in recent years in the number of African nationals engaged in international terrorism. These are the swamps we must drain. We must do so for the cold, hard reason that to do otherwise, we place our national security at further and more permanent risk. We must do so not for liberal, humanitarian or moral reasons, but out of realpolitik recognition that our long-term security depends on it” (Rice 2001:3-4). 
This is the view of Africa Americans who are not African-Americans are afraid to articulate in public. Those who share it do not articulate it in public. For them to articulate it in public they will be accused of racism, particularly by African-Americans. Central to Rice's view of Africa as far as the United States Africa policy is concerned is the importance on the part of the United States in advancing its strategic interests with fear either to lose them or for them to decrease and articulates them by using concerns about its national security and Africa's development. They camouflage or hide what Simon Barber maintains are issues of "fear, greed and pity" upon which, according to him, the United States Africa policy is built (Barber 1999:2). The view that Africa is the threat to the United States national security calls upon the United States to continuously adapts its tactics to its real or perceived safety and security requirements and challenges.

Central to the task of the exercise of state power by political leaders and provision of societies with direction in their internal and external relations is the protection of their citizens through government and platform for them to serve truly as the first line of defence of their countries. Concerns of leaders of all countries in dealing with the enemies, opponents or rivals of their homelands through their foreign policy are primarily national. Despite their different and antagonistic political, economic and ideological positions on international relations and foreign policy issues, processes and developments, international relations and foreign policy theoreticians and practitioners agree on this strategic view of the service of foreign policy to the domestic policy of any society. To the extent that foreign policy is a reflection, if not an extension of domestic policy of the society and domestic policy is a mirror of the structures underlying the relationship between its members constituted by its social fabric (Makgetlaneng 2004:38-39), South Africa's response and preparation for its response to programmes of action of its enemies and opponents or rivals should be characterised by a substantial increase in the strategic investment on its national security continentally and globally with Southern Africa as a primary focus of operations.

Apartheid South Africa served as "the front-line manager and police of the combined interests of the major capitalist powers and their military-industrial and nuclear centres" (Mueshihange 1981:9) in the region. Given this service, they ensured that these interests survived the end of its apartheid rule. It was expected that they will continue using various means for post-apartheid South Africa to serve as a safe field for their survival. Given their victory and post-apartheid South Africa's global, continental and regional strategic importance, they will continue adapting their tactical means to safety and security requirements and challenges striving to remove real or perceived and present or future threats to their interests. What should South Africa do? 
The strategic investment on South Africa's national security in Southern Africa lies with the struggle for it and its regional allies to determine and control their programmes of action and limitations in foreign policy. To achieve this objective, it is critical to recognise that a country's foreign policy effectiveness and power are based not so much on its military strength and economic power, but on strategic efficacy and pursposefulness commanding and enjoying a broad national support. This is despite its internal economic weaknesses, social problems and constaints imposed on it by global capitalist political, economic and ideological order (Nolutshungu 1994:133-34). They should also recognise that this strategic perspective is a key to a successful foreign policy. Central to it is that a country's foreign policy depends on its satisfactory advancement of the popular national interests for its success regardless of how this programme of action is viewed by "foreigners, foes and foes" view this programme of action (Mbeki 2003:54).

This task is crucial in confronting challenges the country faces in its internal and external relations. These challenges are "the dilemma" in which lies question Ibbo Mandaza maintained in in his paper presented at the Seminar on Post-Apartheid South Africa and its Neighbours, National University of Lesotho, Maseru, Lesotho, April 23-25, 1991 that post-apartheid South Africa must answer in its national and international relations in its efforts to achieve objectives of the national liberation struggle. He pointed out that "the dilemma for the new South Africa" lies in the following questions:

"How to rectify three centuries of colonial and racial domination without upsetting the very historical, political and economic bases upon which the Southern African sub-system has been built! How, on the one hand, to seek to resolve the Land Question in a country in which $87 \%$ [of the land] is owned and occupied by a white minority that constitutes only $4 \%$ of the population and, on the other, still hope to leave the structure of production intact. How to address the problem of wages and improved conditions of living for the mass of the people while ensuring that the rate of capitalist exploitation and economic growth remains constant. How to pursue the democratisation of the education and health systems without building a budget deficit that will in turn distort the economy and enhance unemployment and social unrest. In short, how to pursue the objectives of liberation including that of the restoration of the dignity of the African person after centuries of white domination - to its logical conclusion without falling victim to white-mail at home and abroad" (Mandaza 1991:8). 
These are challenges South Africa is facing in its domestic and foreign policies. It is on these challenges that its political leadership's provision of direction in its internal and external relations particularly in dealing with national and international finance capital is tested. They are key reasons why it should strategically and increasingly invest on its national security in Southern Africa. As an integral component part of global capitalism whose internal situation cannot be adequately and fully analysed and concretely understood in isolation from this social order, in executing this task, it should not lose sight of what is taking place externally throughout the world. It should also implement adequate policy measures in dealing with continental and global developments.

\section{Conclusion and Recommendations}

This work has provided key factors characterising South Africa's global, continental and regional strategic importance as viewed by individuals of different and antagonistic political, economic and ideological positions. Central to their view is that South Africa is of vital importance in its contribution towards global, continental and regional transformation. It is expected to contribute towards the establishment of the community as the basis of social existence globally, continentally and regionally. Directly related to its global, continental and regional importance and a high level of expectations and demands placed upon it to contribute towards a new Southern Africa, Africa and the world satisfying exigences of their people is that its leaders should invest in its sustainable national security starting in Southern Africa.

This work concludes by providing recommendations on what South Africa should do in its strategic investment on its national security in Southern Africa. Its leaders should not view the South African people as the strategic asset they possess for the advancement of their interests.

Leaders of unassailable quality should direct their programmes of action to prepare today what they will face tomorrow. The substantiation of their theoretical position that they are servants of the country and its people in practice must reflect the link between knowledge and power in which the South African people view themselves as historical subjects with power not only to transform their country, but also, most importantly, as the foundation against subversion of structures of their power and authority by internal and external enemies.

Leaders of unassailable quality should direct their programmes of action to prepare today what they will face tomorrow. The substantiation of their theoretical position that they are servants of the country and its people in practice must reflect the link between knowledge and power in which the South African people view themselves as historical subjects with power not only to transform their country, but also, most importantly, as the foundation against subversion of structures of their power and authority by internal and external enemies. 


\section{References}

Barber, S (1999), "US Policy Built on Fear, Greed and Pity", Business Day (Johannesburg), 26/5/1999.

Castells, M (1996), The Information Age: Economy, Society and Culture: Vol. 1: The Rise of the Network Society. Malden, Massachusetts: Blackwell Publishers.

Castro, F (1998), "Speech delivered by His Excellency Dr. Fidel Castro Ruz, President of the Council of State and of the Ministers of the Republic of Cuba, to the South African Parliament, on 4 September 1998", Cape Town: Parliament.

Cherry, D (2002), "Desperate African Presidents Court Self-destruction in NEPAD Plan", Executive Intelligence Review, Vol 29, No 23, pp 19-22.

Glotzer, R (2009), "C.W. de Kiewiet, Historian of Africa: African Studies and the American PostWar Research University", Safundi: The Journal of South African and American Studies, Vol 10, No 4, pp. 419-447.

James, CLR (1963), The Black Jacobins: Toussaint L'Ouverture and the San Domingo Revolution, New York: Vintage Books.

Jordan, P (2004), “A Space for Africa to Define its Future”, ThisDay (Johannesburg), 19/3/2004. Kikwete, JM (2012), in Loyiso Langeni (ed), "South Africa confident of winning African Union post”, Business Day (Johannesburg), 27/1/2012.

Makgetlaneng, S (2004), “The New Partnership for Africa's Development and the penetrated nature of the socio-political and economic system of African countries", Politeia: Journal for Political Sciences and Public Adminisration, Vol 23, No 1, pp. 33-49.

Mandaza, I (1991), "Southern Africa in the 1990s: Resolving the South African (National) Question", Southern African Political \& Economic Monthly, Vol 4, No 8, pp. 4-13.

Mandela, N (1997a), "Closing Address by President Nelson Mandela at the Summit of the Heads of State and Government of the Southern African Development Community on 8 September 1997”, Blantyre, Malawi.

Mandela, N (1997b), "Opening Address by President Nelson Mandela at the Summit of the Heads of State and Government of the Southern African Development Community on 8 September 1997”, Blantyre, Malawi.

Mandela, N (1993), "South Africa’s Future Foreign Policy," Foreign Affairs, Vol 72, No 5, pp. 86-97.

Mbeki, M (2003), “Towards a More Productive South African Foreign Policy", South African Yearbook of International Affairs 2002/03, Johannesburg: South African Institute of International Affairs.

Mbembe, A (2019), “Achille Mbembe interviewed by Andreas Eckert, "If we don't rehabilitate reason, we will not be able to repair our broken world", Mail \& Guardian (Johannesburg), 10 to $16 / 5 / 2019$.

Mbembe, A (2008), "Politics of pigmentation mars regeneration", Sunday Independent (Johannesburg), 3/8/2008. 
Mueshihange, P (1981), "Statement of Comrade Peter Mueshihange, SWAPO's Secretary for Foreign Relations, before the United Nations Security Council on 23 April 1981", Namibia Today: Official Organ of the South West Africa People's Organisation, No 7, pp. 1-28.

Nkrumah, K (1970), Neo-Colonialism: The Last Stage of Imperialism, London: Panaf Books.

Nolutshungu, SC (1994), "South Africa's Position in World Politics", in Maphai, V (ed.), South Africa: The Challenge of Change, Harare: SAPES Books, pp. 128-36.

Rice, SE (2001), "September 11, 2001: Attack on America: Testimony of Dr Susan E. Rice Before the House of Representatives International Relations Committee Subcommittee on Africa, the United States House of Representatives on Africa and the War on Global Terrorism on 15 November 2001”, Washington, DC: U.S. Government Printing Office.

Rice, SE (1999), "United States Interests in Africa: Post-Cold War, Post-Apartheid", May 1999 Bram Fischer Memorial Lecture to the Rhodes Scholars Southern Africa Forum, Oxford University, England on 13 May 1999, Oxford University: England.

Tambo, OR (1977), O.R. Tambo speaking at the Umkhonto we Sizwe military camp in Angola in 1997, Angola. 